\title{
Self-medication in Skin Conditions: A Cross Sectional Survey
}

\author{
Mubashar Mashqoor Mir ${ }^{1 *}$ and Mohammad Sarwar Mir ${ }^{2}$ \\ ${ }^{1}$ Post Graduate Department of Dermatology, India \\ ${ }^{2}$ Department of Hospital Administration, India \\ *Corresponding author: Mohammad Sarwar Mir, Senior Resident, Department of Hospital Administration, India
} Submission: 眥June 01, 2018; Published: 眥June 25, 2018

\begin{abstract}
Self-medication involves individuals or their carers administering a medical drug of their own choice for symptomatic relief and in the hope of a "cure", without seeking professional medical advice. The aim of this descriptive cross-sectional study conducted at was to identify the occurrence of selfmedication for the topical treatment of skin diseases in community. We observed 50 cases of self-medication (from a total of 500 subjects).
\end{abstract}

Keywords: Self medication; Skin diseases; Cross sectional survey

\section{Introduction}

Self-medication is a term used to describe the various ways in which the individuals or those responsible for them decide on which drug to administer for symptomatic relief or "cure", without seeking a professional medical evaluation of their condition [1]. Selfmedication can involve sharing other people's drugs, using left over prescriptions or failing to use medicines prescribed by professional medical practitioners [2,3]. In developed countries the prevalence of self medication varies between $30 \%$ and $90 \%$ [4-7].

The most commonly-used drugs are analgesics, antipyretics and NSAIDs $[8,9]$. The misuse of topical substances can result in bacterial resistance, hypersensitivity reactions, dependence, withdrawal symptoms etc. Furthermore, the temporary relief of symptoms can mask a disease which goes undetected and can progress to a more serious condition.

\section{Material and Methods}

A cross-sectional descriptive study of a community was carried out treated aimed at identifying the

occurrence of self-medication in the topical treatment of skin diseases

\section{Inclusion criteria}

Patients had used a medication before specialist consultation. A standardized questionnaire was applied with a view to evaluating the occurrence of self-medication prior to the consultation [10].
Questions referred to the type of drug used, who indicated the particular substance, why it was decided to use non-prescription medication and whether any changes in the patient's clinical status had been noticed after using the drug.

\section{Results and Discussion}

Of the Self-medication is common, yet often goes underreported. The fact that some skin diseases are self-limiting and benign encourages, with the result that patients frequently do not see the need to seek professional advice from dermatologists.

Of the 50 patients who met the inclusion criteria, 30(60.0) were males and 20(40.0\%) were females. Drugs were recommended by family members or friends (48.0\%), pharmacy employees $(20.0 \%)$ or by doctors from some other branch of medicine (Table 1 ).

Table 1: Most common self medications.

\begin{tabular}{|c|c|c|}
\hline Drugs & Frequency & Percentage \\
\hline Anti acne creams & 20 & $40.0 \%$ \\
\hline Topical steroids & 15 & $30.0 \%$ \\
\hline Combinations & 8 & $16.0 \%$ \\
\hline Others & 7 & $14.0 \%$ \\
\hline
\end{tabular}

The most commonly-used drugs encountered in our study were: anti-acne preparations (27.5\%), corticosteroids and combinations (corticosteroids, antibiotics and antifungals). Others included moisturizers and barrier creams. The high prevalence of 
acne (particularly facial) in the younger population undermines the self-esteem of individuals and drives them to seek some form of treatment, often encouraged by media advertising which fuels the growing demand for anti-acne products.

\section{Conclusion and Recommendations}

Our study revealed that self-medication is quite common in skin conditions .It is important that people in our society should be given impartial scientific information on the nonprescription drugs freely on sale, in the hope of reducing massive consumption and the myth of a cure promised by these products. One further important point: people should be encouraged to seek professional medical help from the experts and made aware of the postive advantages to health of a proper medical consultation rather than resorting to self-medication.

\section{References}

1. Padoveze EH, Nascimento LFC, Ferreira FR, Neves VSC (2012) Crosssectional descriptive study of topical self-medication in a hospital dermatology department in the state of são paulo. An Bras Dermatol 87(1): 163-165.
2. Paulo LG, Zanini AC (1998) Self-medication in Brazil. Rev Ass Med Bras 34: 69-75.

3. Arrais PSD, Coelho HLL, Batista MCDS, Carvalho ML, Righi RE, et al. (1997) Profile of self-medication in Brazil. Rev Saude Publica 31(7): 7177.

4. Johnson RE, Pope CR. (1983) Health status and social factors in non prescribed drug use. Med Care 21(2): 225-233.

5. Lam CLK, Catarivas MG, Munro C, Lauder IJ (1994) Selfmedication among Hong Kong Chinese. Soc Sci Med 39(12): 1641-1647.

6. Francis S VT, Pereira FB, Stephan C, Cordeiro R (2007) Self-medication in children and adolescents. J Pediatr 83(5): 453-458.

7. Bush PJ, Osterweis M (1978) Pathways to medicine use. J Health Soc Behav 19(2): 179-189.

8. Segall A (1990) A community survey of self-medication activities. Med Care 28(4): 301-310.

9. Haak H (1989) Patterns of drug consumption in two villages in Bahia (Brazil). Public Health Rev 23: 143-151.

10. Vilarino JF, Soares IC, Silveira CM, Rödel APP, Bortoli R, et al. (1998) Profile of self-medication in a municipality in southern Brazil. Public Health Rev 32: 43-48.

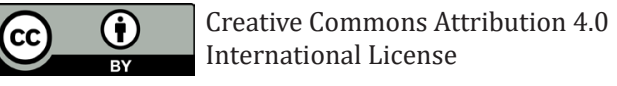

For possible submissions Click Here

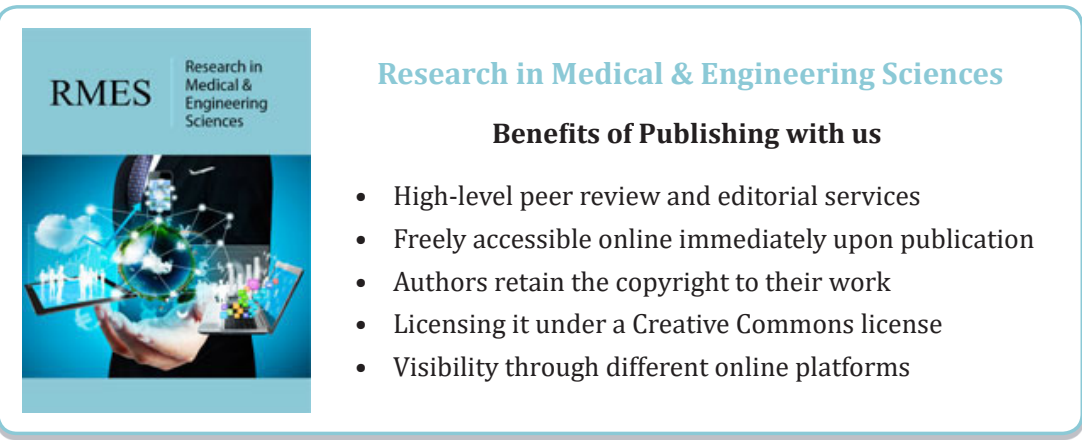

